\title{
Sustainable and social quality of refugee housing architecture
}

\author{
Michael Eichner ${ }^{1}$ and Zinaida Ivanova ${ }^{2, *}$ \\ ${ }^{1}$ German University in Cairo - GUC, New Cairo City - Main Entrance of Al Tagamoa Al Khames, \\ Egypt \\ ${ }^{2}$ Moscow State University of Civil Engineering, Yaroslavskoe shosse, 26, 129337, Moscow, Russia
}

\begin{abstract}
The article analyses the relationship between sustainable architecture, social integration of refugees and innovative urban development, unfolding the synergetic potential between these questions. The authors consider that a successful integration of migrants with different cultural background, education and income level can be best achieved through buildings and urban districts, designed according to international sustainable principles. Not less innovation, but more is the key to address global challenges for spatial development of cities of any scale. Today it is not the limitation of financial resources for refugee housing programs that poses a threat to social, balanced and economically successful development of housing environments in cities, but the lack of knowledge of sustainable planning principles and sustainable construction techniques. The authors conclude: Whereas in central Europe socio-cultural and environmentfriendly strategies for cities are widely in place, eastern Europe, Russia and north Africa or the Middle East region has not yet implemented such strategies as short- and long-term planning instruments. The article presents the urban case study project for a sustainable urban extension of the city of Luxor (Egypt) by the architect M. Eichner, Professor at the German University in Cairo - GUC.
\end{abstract}

\section{Introduction}

The concept of sustainable development of urban settlements adopted by the United Nations presupposes providing the population with a high standard of living while at the same time preserving and recovering natural resources and ecological balance. Important elements of the criteria of sustainability include:

- a consistent increase in the living standard and well-being of the population;

- social protection of people with disabilities and financially disadvantaged citizens;

- formation of a modern housing market, providing financially disadvantaged citizens with municipal housing;

- integration of representatives of different ethnic groups into the social environment of a city, cultivating tolerance

of the urban population in relation to each other;

\footnotetext{
*Corresponding author: ivanovazi@mail.ru
} 
- providing real conditions for the cultural development of all ethnic minorities.

These sustainability criteria are coming to the forefront due to the rapid increase of population migration in the world. According to the United Nations, the number of migrants in the world in 2015 amounted to 244 million people [1]. The number of internally displaced persons around the world in 2016 increased by 300 thousand compared to 2015 and amounted to 65.6 million people. This follows from the annual report of the United Nations Refugee Agency "Global Trends", published on June 19, 2017 [2]. 22.5 millions of the total number of internally displaced persons on the planet are refugees; 40.3 million are displaced in their own countries; 2.8 million are in have the status of asylum-seekers [3]. The governments of states, to where refugees migrate, face problems not only of receiving them, but also of investing in job creation and construction of housing.

\section{Literature review}

In recent decades scientific literature extensively discusses issues of implementation of sustainable principles in construction, architecture and urban development. Researchers note that these notions are closely related and include not only ecological and energy-efficient questions but to a greater extent social objectives. We speak about creation of comfortable living environments for current and future generations [2,3,4,5,]. Scientific work deals with the tremendous challenges related to the faces of modern cities and forms the discussion on implementing concepts of sustainable development and sustainable growth with regard to regional and national problems $[6,7,8]$. The DGNB schemes for sustainable districts provide a powerful and comprehensive system for guiding principles in the field of resource saving and integrative urban neighborhood development [23] which were applied during the concept design phase of the sustainable urban case study project for Luxor by the German university in Cairo GUC. An article of A. R. Haliullin considers current tendencies of architectural design from the point of ecological, economic, social and other aspects with particular emphasis of regional social factors. The author presented a unique model named "mobile eco-sustainable architecture" [12]. In this article, I.V. Dianova-Klokova and D.A. Metanyev consider the European experience (Finland, University of Joensuu; Netherlands, Delft University of Technology) and the North American experience (Canada, University of Ontario Institute of Technology, USA, Florida Polytechnic University and others) of building certification according to modern national standards [13]. The analyzed examples successfully combine the principles of interdisciplinarity, ecological compatibility, developed social engineering and openness, promoting emergence of innovation and creativity. The projects place emphasis on social significance of innovation in the designs of planners.

Issues of implementing sustainable development principles of a city in the context of mass migration and the formation of a complex multicultural population have been widely discussed recently [11-13]. The main question is, how refugee housing can be realized to meet the needs of inhabitants of existing cities, of the newly arriving population of refugees and of future generations, and how to develop new districts that are socially balanced and economically viable $[17,18]$. Politicians, researchers, planners and builders equally discuss which direction has to be taken to cope with the increasing demand of affordable mass housing due to population growth and migration streams while avoiding mistakes of mass housing programs of the 1960's and 70's, which in many countries resulted in urban districts of with a low standard of living and stigmatization of entire segments of the population. The German Lower Saxony parliament followed a new direction by adopting a strategy paper where "the concept of pre-occupancy" of buildings with refugees as a first stage for newly built housing, applied in Lower Saxony can also contribute to the accommodation of refugees in order to achieve a desirable mix of residents in the neighbourhoods and avoid 
stigmatization in newly built areas and open a way for later social and commercial use of the new housing stock. This complies with sustainable urban design requirements for more flexible, gender and generation friendly design of urban districts with buildings, taking into account easily adaptable construction, technology and floor planning solutions.

\section{Materials and methods}

The main research method applied by the authors is document analysis and case study urban planning. UN statistics, scientific articles, governmental decisions and actions of the legislative bodies, architectural projects of economy-class residential houses aimed for financially disadvantaged citizens and implemented in some countries were obtained for analysis. The urban case study master plan was developed in cooperation with the municipality of the city of Luxor/New Tiba and the government of Luxor, to explore the potential of modern sustainable principles (DGNB German sustainable building council) for social, integrative and economic extension of the existing town New Tiba. The aim of the authors is to gather and apply existing ideas in case study projects to explore architectural and urban planning solutions for refugee resettlement problems and supply of housing typologies complying with requirements of different ethnic groups and their integration into the social environment of cities. The authors studied Germany extensively as a country with exceptional experience in resettling and integrating refugees where numerous social programs concerning the integration of refugees and migrant workers have been implemented. Moreover, the article presents an architectural project of the author M. Eichner, the Professor of German University in Cairo - GUC.

\section{Results}

\subsection{Position of professional associations}

The often realized container village solution with simple and quick to build low-rise container housing for refugees faces increasing resistance, not only by existing populations and refugees themselves, but in particular from specialist associations such as the architects' chambers. They claim, that substandard and hastily constructed buildings are not a sustainable solution for our cities, and are lacking in social responsibility in the short and long-term. Here, of all actors more courage is required to find improved, contemporary social housing solutions. Consideration of the architectural history of social housing in cities such as Vienna, Berlin, Munich and others reveal the potential for our cities to shape the future with innovative and architecturally high-quality solutions. Social housing programs should be innovative and future orientated, quick to build buildings yet with high technical, social and energy-efficient standards. A recently published statement of the German Chamber of architects asserts, "Buildings where refugees live permanently are to be planned and built in the same way as other dwellings to avoid stigmatisation and ghetto developments. A departure from hitherto properly regarded planning and building standards and principles only for refugee housing leads to additional problems and will make the integration even more difficult" [17]. Refugee housing often means speedy construction at the expense of beauty and quality, but that doesn't have to be the case. The German sustainable building council have "expressed their opposition to hastily constructed functional buildings" and quoted in this question, that especially in the context of the refugee debate and argued that a so-called softening of modern construction standards for the realization of refugee housing 
buildings should be avoided" (DGNB, Zielkonflikt im privaten Wohnungsbau). Nothing completely new, but in general better social housing is necessary.

\subsection{Innovative potential for construction of refugee housing buildings}

The authors consider the potential and possibilities of construction of social, integrative mixed-use housing districts according to current sustainable standards like the German DGNB standard, suitable for temporary or permanent integration of refugees of different cultural background to be both extremely important and inevitable. In particular a deeper analysis and consideration of the specific sustainability requirements for Socio-cultural and Functional Quality in urban districts including the criteria "Social and Functional Mix", "Objective / Subjective Safety", "Inclusive Access" and "Urban Integration" (DGNB urban districts, overview criteria, version 2012) positively influences the social atmosphere of newly built urban areas. On a building scale several recently realized housing complexes, adaptable during the entire life cycle document the possibility of innovative architectural solutions for social housing buildings with limited economic budgets. One of the first of these projects is the "Aktivhaus Series" in the city of Winnenden; refugee housing in different urban environments focussing primarily on energy efficiency and smart energy grid integration. This refugee housing complex, realized in 2016 demonstrates the possibility to take into consideration the latest sustainable requirements for ecologic, climate saving and healthy building design, in compliance with budget limits for social housing. The building complex is designed and realized, meeting the 6 main sustainable criteria fields of environmental, economic, sociocultural and functional, technical, process and site quality criteria. As a self-sufficient and modular constructed refugee complex for 200 Syrian refugees, it was erected in a very short construction time of 12 weeks through factory prefabricated and integrated building technology for electrical, ventilation and drainage systems as well as all window and doors. Solar energy production of up to $200 \%$ of daily consumption needs results in a surplus of produced energy that can be sold or stored in-house, supported by a smart energy supply network with neighbouring buildings. The building systems allow for enough energy production for additional e-cars or e-bikes as e-mobility. The floor planning follows a flexible concept and can be adapted to different user groups and households. Planned as refugee housing for three years, the project will then be converted into social housing. To summarise, the building produces neither $\mathrm{CO} 2$-emissions nor waste during reconstruction or demolition. It represents a showcase project for different rural and metropolitan areas in cities worldwide.

\subsection{Government role in housing programs for refugees}

The governmental role in stimulating and regulating social housing programs to provide low cost and future orientated living environments to refugees within existing urban contexts is, according to government representatives, currently being reinvented in Germany. The Federal Ministry for construction has eased and simplified laws for housing construction. The focus for the integration of larger numbers of refugees and related new construction sites lies within the German capitals and university cities. Existing building regulations are being reconsidered for adaptation and simplification, further increase of requirements such as the energy saving regulation (Energieeinsparverordnung - EnEV) will be postponed and requirements for cost-intensive parking spaces per housing unit will be temporarily reduced. Important flanking measures have also been implemented with maximum rental limitations and increased social housing allowances. According to the Federal Minister of Construction there is a new dynamic in the innovative housing market in Germany again. He emphasized, "housing construction is once again a key social policy issue". 


\subsection{New Luxor - sustainable and refugee friendly master plan}

First mayor cities in Egypt, with tremendous migration and population growth challenges due to a yearly growth of up to 2.1 million inhabitants, turn to urban development according to sustainable principles as common planning approaches. Traditional mass housing building typologies have proved neither to meet people's requirements nor to be environment-friendly solutions. A recent 180 degree shift in the urban planning strategy was demonstrated by the government of Luxor, by the initiation of a case study for a sustainable development strategy for its new districts from the German university of Cairo GUC and Prof. M. Eichner. According to the city administration two large-scale new urban areas with up to 200,000 inhabitants in New Tiba and up to 800,000 inhabitants in New Luxor district will be realized as satellite towns outside the historic and farmland districts over the next 30 years to address the market demand for new housing for the growing local population, migrants from the neighbouring African countries and national, as well as international, tourists. The construction of standardized mass housing typologies, developed between the $1950 \mathrm{~s}$ and 1980s for Luxor and other Egyptian cities was stopped as they proved unsuccessful on the current real estate market.

The project aim was to transform the two areas into multi-facetted model districts of regional and international importance, based on the latest sustainable and ecological urban quality principles. For both sites, on the northern and eastern city border of Luxor, new multifunctional and mixed used housing neighbourhoods were planned, integrating a convention and exhibition centre, an Olympic sports and training centre, a museum complex and a business downtown, surrounded by different innovative housing typologies. The master plans form the framework for New Tiba and New Luxor to develop into an international destination for administration, conferences, events and sports according to socio-economic, ecologic and technologic requirements, providing new housing projects for local needs of people and make it an attractive destination for visitors and inhabitants by improving opportunities to accommodate large cultural events, conferences, sport events and convenient environmental friendly living conditions. The districts will be self-sustaining in food and energy production as well as in providing workplaces and areas to attract small and medium size businesses with non-polluting business models. Focusing on resource efficiency led to using local construction materials and building technologies like rammed earth constructed low-rise housing, with pedestrian friendly neighbourhood design, integrating natural topography into the city structure, supporting the use of public transport and creation of innovative new forms of landscape areas, parks, generation- and gender-friendly living districts (Fig. 1).

The urban master plan provides districts with healthy living and working environments, secure urban spaces with a high quality of life and reduced car traffic, integrating workplaces both for local inhabitants and international business structures (Fig. 2). 


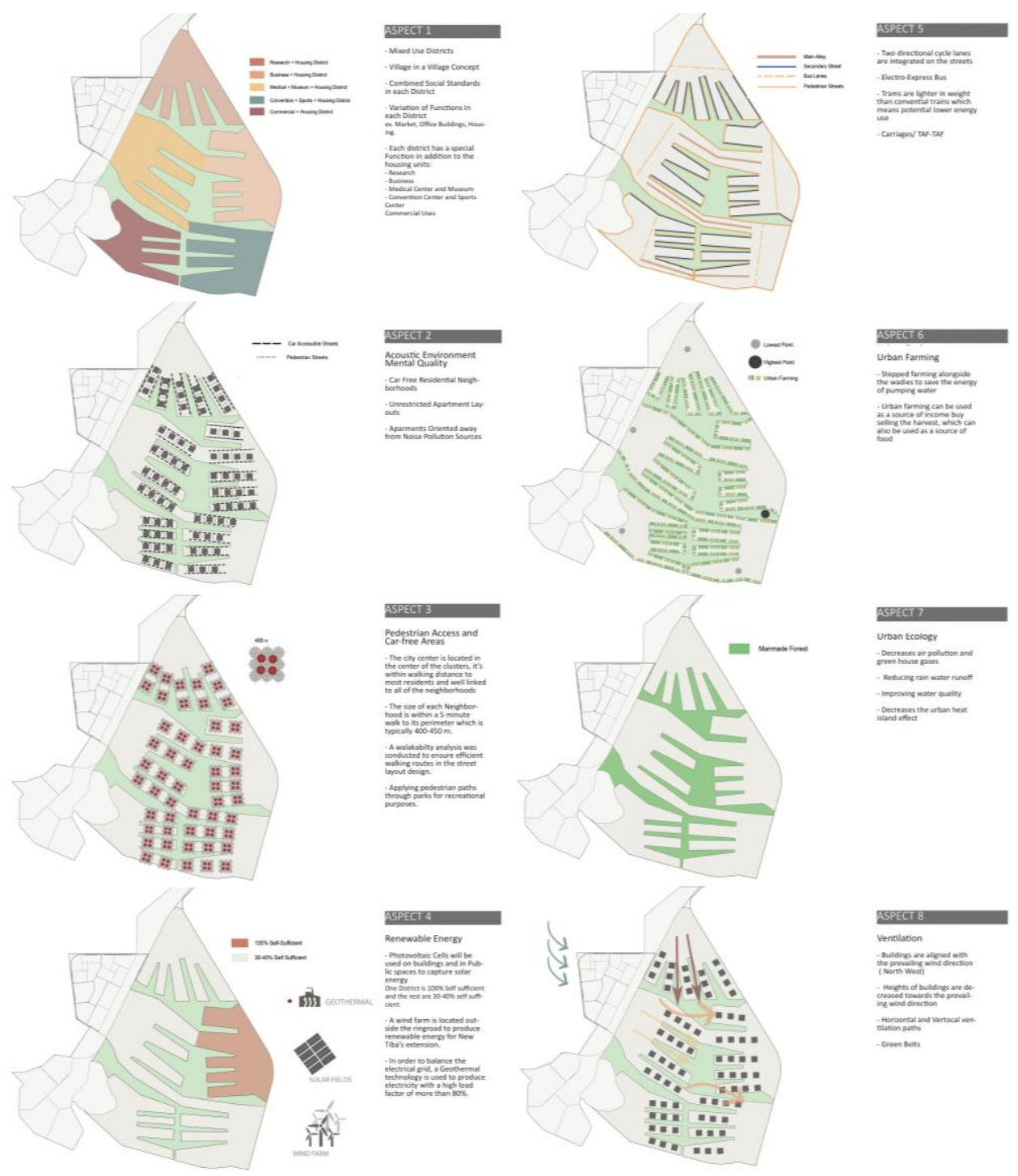

Fig. 1. Sustainable urban evaluation, master plan New Tiba, Luxor, GUC, Prof. M. Eichner, 2017.

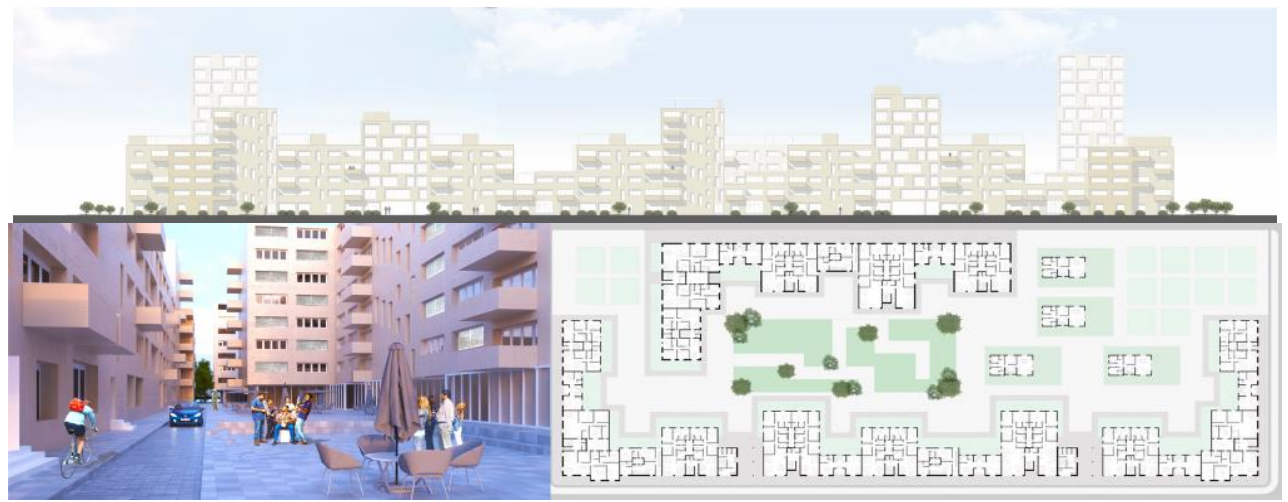

Fig. 2. Car reduced mixed-use housing neighbourhood, Luxor, GUC, Prof. M. Eichner, 2017. 
A network of green desert parks, urban gardening areas and man-made forest park zones play an integral role in the quality of life and the atmosphere in New Luxor, maximizing special convenience and air quality as well as reducing environmental impacts. With passive design strategies and active building typologies all consumed energy being used in buildings is generated on-site or in nearby locations. The concept for the "Green Desert Town" will be self-sustaining in food production and energy generation, resource efficient through using local construction materials for buildings and infrastructure, innovative with new forms of education and health care facilities as well as of high social and recreational quality (Fig.3).

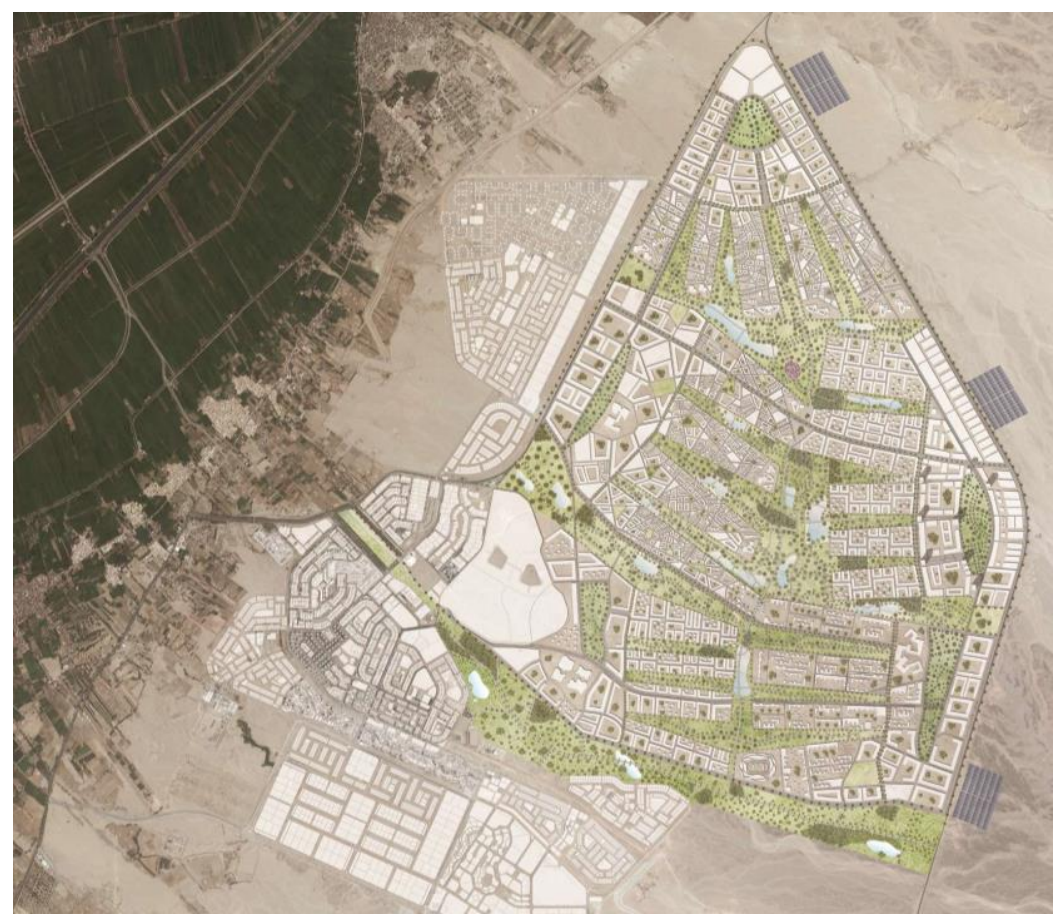

Fig. 3. Urban reconstruction and development plan New Tiba, Luxor, GUC, Prof. M. Eichner, 2017.

\section{Discussion}

\subsection{Housing Market situation in western countries}

Currently in Germany there are 4 million social apartments missing. Only 1/5 of low-income households currently have the chance to get social housing accommodation and only 30,000 newly built social housing units have been introduced into the market in 2015 . There should be at least 130,000 new residential units each year. Currently, the ten major German cities with the strongest housing shortage lack more than 100,000 rented apartments - some 17,500 of them in Frankfurt am Main alone and 8,000 in Stuttgart. By 2017 a total of 825.000 social apartments for rent have to be built in Germany.

\subsection{German government strategy for a sustainable integration of refuges}

The German government expects, that around 350,000 apartments are necessary per year to integrate refuges. To stimulate the low cost housing market, increased tax reduction reaching $35 \%$ of the construction costs for investors of refugee housing projects have been adopted. 
An expected 2 billion Euros per year till 2020 will be spent to realize this increase in social housing buildings. Federal financing programs intend to strengthen decentralization in urban districts, with a focus on education, employment, trade and adult education while promoting affordable housing in urban agglomerations and university cities, stimulating existing social housing programs with benefits for students, low-income people and refugees at the same time. The financing programs of the German government-owned development bank KfW play an important role. Through the KfW Bank (Kreditanstalt für Wiederaufbau) an additional financing program for refugee housing projects was set up. The KfW offers special support to municipalities for the rapid establishment of initial accommodation for refugees. 1 billion Euros in 2015 were available for this purpose. "This funding sum has been fully retrieved," declared the Minister of State at the Federal Chancellery and refugee commissioner, Peter Altmaier, at a press conference in Berlin. In view of the strong demand, the program was increased by EUR 500 million in order to be able to meet all the requests submitted, according to Altmaier. This could result in a total of up to 150,000 refugees placed in first homes.

\subsection{Low Cost refugee Housing, Karlstadt, Wuerzburg}

Another refugee construction project, implemented by the Bavarian Ministry for Construction and Transport, is combining sustainable solutions and economic restraints, achieving a highly integrative living environment for refugees in the short term and high quality yet affordable social housing in the long term by additionally meeting climate saving and energy-efficient standards (Fig. 4). It was permitted to build implementing reduced space and construction standards, applying the following solutions:

- Construction as CO2-emission saving prefabricated wooden frame system;

- Minimized and centralized technical installation;

- Cost saving outside staircases;

- With central social facilities like administration, social care service rooms, multifunctional space for residents;

- Apartment units with a reduced living space of approx. $45 \mathrm{~m}^{2}$ each;

- Flexible apartments for families with max. 2-3 children or communal living;

- Cost efficiency through square meter reduction per person;

- Minimized staircase and corridor areas within the building envelope;

- No basement or underground parking;

- High degree of prefabrication of the building elements;

- Reduced parking space ratio per household in coordination with the city of Karlstadt;

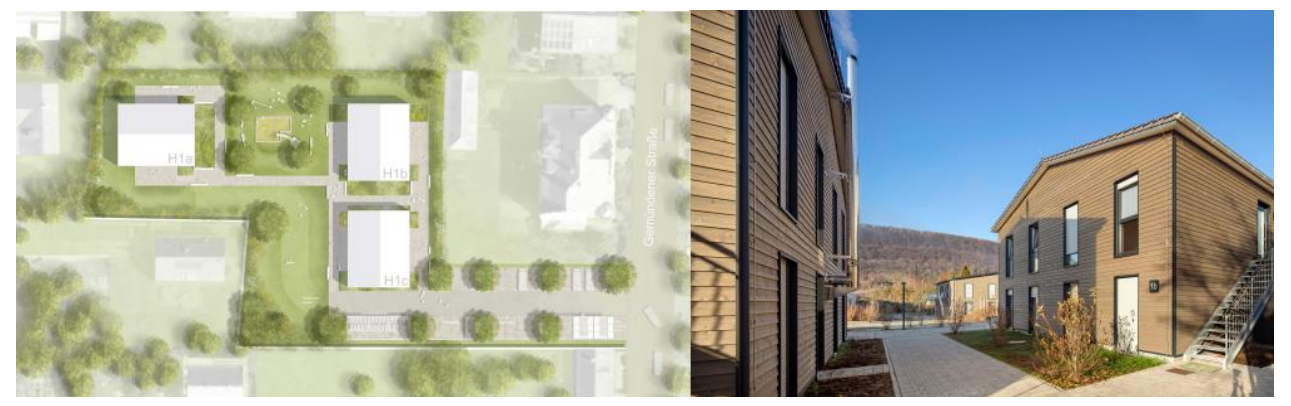

Fig. 4. Refugee housing complex in Karlstadt, Bavarian Ministry of the Interior, Building and Transport. 


\subsection{Holistic planning of integrative housing buildings}

To achieve integrative urban quality and apply holistic urban development strategies the so called SNAP-TOOL (Systematic Sustainable requirement evaluation) was developed by the German Ministry for Transport, Construction and Urban development BVBS, supporting planners and other decision makers to address the tremendous challenges arising with the complex balancing of partly contradicting aims like resource saving, energy-efficiency, social and cultural requirements including the urban transformation caused by migration, refugees and rapid population growth. While applying the method for sustainable concept findings with SNAP recommendations on a building and urban scale, based on sustainable and social principles, key questions can be approached and relevant sustainable criteria can be considered in different planning phases, starting from competition or concept phases to realisation or exportation phases. Municipalities as well as individual planners are capable to handle sustainable pre-examination and decide to which detail sustainable criteria are qualitatively or quantitatively reviewed.

\section{Conclusions}

Numerous realized housing districts under strong consideration of socio-cultural, economic, ecologic and technologic requirements show that refugee housing can be of higher architectural quality, cheaper erected and exploited as simple container solutions or temporary buildings. Such examples finally significantly contribute to the sustainable development of cities and metropolitan areas and at the same time contribute to a climate saving building culture. Implementing social integration of refugees and minority groups through sustainable and innovative architecture requires from all actors in the field of construction, urban design, political decision-making and financing to acquire a deeper understanding of sustainable principles and arising cultural and economic potentials. Assessment methods based on sustainable criteria will allow quality-of-life improvement in the cities of Eastern Europe, Russia and North Africa or the Middle East region and guide their architectural and urban planning processes in a more integrative way, requiring significant restructuring of administrative and construction permission procedures by taking sustainable requirements in all stages into account. The systematic sustainable requirement evaluation is in many capitals already successfully applied, a strategy, not only for developed western countries but also for developing countries.

This article is written within the framework of Erasmus+ Programme - Jean Monnet project entitled "Migration processes and urban design: EU experience". The ideas stipulated in this article are solely based on the views of its co-authors.

\section{References}

1. Integration von Flüchtlingen, Positionen und Forderungen des Niedersächsischen Städtetages (Einbeck, 2016)

2. T. Hak, Sustainability Indicators, Scope 67 (Island Press, London, 2007)

3. R.W. Kates, Harvard University. Cambridge, CID Working Paper, 213 (2010)

4. A.Ju. Sogomonov, Municipal'naja vlast' 5, 20-32 (2016)

5. A.Ju. Sogomonov, Municipal'naja vlast' 1, 18-27 (2017)

6. G.V. Esaulov, Vestnik TGASU 6, 9-23 (2014)

7. O.K. Capieva, D.A. Denevizjuk, M.M. Agaragimov, Regional'naja jekonomika: teorija i praktika 7(46), 64-70 (2007) 
8. J. Gehl, Cities are good for you: The Genius of the Metropolis (Conville \& Walsh Ltd. and Synopsis Literatary Agency, 2013)

9. D.Yu. Lomakina, Gradostroitel'stvo 2, 64-70 (2010)

10. I.V. Dianova-Klokova, D.A. Metanyev, Arhitektura i stroitel'stvo v Rossii 7(211), 1731 (2015)

11. A.C. Helderman, M. Van Ham, C.N. Mulder, Tijdschrift voor Economische en Sociale Geografie 2(97), 111-125 (2015)

12. Ch. Landry, The Intercultural City: Planning for Diversity Advantage (Phil Wood and Charles, Earthscan London - Sterling, 2008)

13. The Relationship between Population and Housing (The link between Housing and Migration) (United Nations, 2010)

14. Hospitality architecture: students have developed housing for refugees (Germany), http://www.altyn-orda.kz/arxitektura-gostepriimstva-studenty-razrabotali-zhile-dlyabezhencev/

15. Modular, prefabricated housing for refugees, https://ardexpert.ru/project/5252

16. V.I. Babyak, AMIT 2(27) (2014) http:// marhi.ru/eng/ AMIT/2014/2kvart14/ babyak/ AMIT_27_Babuak_PDF.pdf.

17. A.R. Haliullin, Izvestija KGASU 1(23), 61-69 (2013)

18. N. Brookes, N. Ivanišević, A. Lukasiewicz, T. Sainati, C. lo Storto, Special Purpose Entities in Megaprojects, Transport and Urban Development, Action megaproject TU 1003 (University of Leeds, 2015) ISBN 978-0-9576805-3-1 